\title{
New additions, range extensions and nomenclatural updates for the Hawaiian moss flora, island of Kaua'i, USA
}

\author{
James R. Shevock, Tim Flynn, John C. Game, Wen Zhang Ma, Adam Williams, \\ David R. Toren, Benito C. Tan ${ }^{\dagger} \&$ John R. Spence
}

\begin{abstract}
New additions, range extensions and nomenclatural updates for the Hawaiian moss flora, island of Kaua'i, USA. - Acta Mus. Siles. Sci. Natur., 68: 105-122, 2019.

Abstract: Fifty mosses are reported new for the island of Kaua'i. Sixteen species represent the first collection for the State of Hawai'i and are indicated by an asterisk (*). The moss flora of Kaua' $\mathrm{i}$ is comprised of 170 taxa.
\end{abstract}

Key words: bryophyte inventory, new records, range extensions, species distributions

\section{Introduction}

It has been more than a decade since a revised checklist of Hawaiian mosses was published (Staples et al. 2004). That literature-based work lists 273 native and naturalized taxa known to comprise the Hawaiian moss flora (Staples et al. 2004). Of this total, 120 taxa, or nearly 44\% of the total number, had been documented previously from the island of Kaua' $i$. By comparison, 152 taxa were listed for the nearby and slightly larger island of $\mathrm{O}^{`}$ ahu. Based on herbarium collection data from both the National Tropical Botanical Garden (PTBG) and Bishop Museum (BISH), about 4 times as many moss herbarium specimens have been made from $\mathrm{O}^{`}$ ahu as have been collected from Kaua' $i$. This no doubt reflects $\mathrm{O}^{\prime}$ ahu's role as the state's center of higher education as well as a first stop for most island visitors. This first project to update the moss flora of the state of Hawai' $i$ focusses on the island of Kaua' $i$ since the number of collections available for study is markedly fewer than those available from the larger islands of $\mathrm{O}^{\text {‘ }} \mathrm{ahu}$, Maui and Hawai'i.

We also recognize the great need to conduct a similar study for the hepatics. This task, however, is beyond our capabilities and while we acknowledge the importance of the hepatic Hawaiian flora, especially within the cloud forest environments, we hope other bryologists will focus on this taxonomic group in the very near future. There remains much to document in the hepatic flora within Kaua' $i$ and the other islands in the state of Hawai' $i$.

Kaua' $i$, at $552 \mathrm{mi}^{2}\left(1430 \mathrm{~km}^{2}\right)$, is the fourth largest of the Hawaiian Islands. There is limited road access up to 4200 feet, and the highest peaks on Kaua'i remain difficult to access. Kawaikini at 5243 feet $(1598 \mathrm{~m})$ is the highest point on Kaua'i and neighboring Wai'ale'ale, the second highest peak at 5169 feet $(1576 \mathrm{~m})$ is reported to be among the wettest places on Earth. Many portions of forest reserves are best accessed by helicopter making field work both challenging and expensive. Frequent rainfall and exceedingly steep terrain also make surveying remote areas difficult. The island is divided into land Districts. We have utilized this land division on our specimen labels as another way to visualize the distribution of taxa among various land units.

Based on the level of visitation over decades to the Hawaiian Islands, one would assume that the bryoflora of Hawai' $i$ would be well documented; however, several species reported for the state by Bartram (1933) have not been re-collected or observed since. A few of these species are represented by a single collection as the sole basis for a component of the island bryoflora and are likely to be construed as misidentifications once the source specimens are located and 
re-examined. Also, herbarium processing errors can result in inaccurate documentation of collections attributed from the Hawaiian Islands. There also remains a number of moss species reported for Kaua' $i$ that we did not relocate. In addition, there was also a period in the second half of the $20^{\text {th }}$ century when bryologists viewed the number of endemics described from Hawai' $i$ as nothing more than distant range extensions or slight morphological forms and variations of otherwise widespread Pacific Basin species. Many Hawaiian endemics were only known from a handful of specimens. Based on our field work, we are of the opinion that some of the sinking of Hawaiian endemics into synonymy of more far ranging species was not based on strong morphological evidence or detailed examination of Hawaiian collections. We anticipate that some State endemics will likely need to be re-instated based on molecular data. Also in a few cases, species names have been misapplied to Hawaiian material, and therefore, may need to be recognized under a different circumscription.

Historically most moss collections from Kaua'i can be linked to major hiking trails in Koke'e State Park in the northwest corner of the island and along the Kalalau Trail on the north side of the island. These collections most often represent just a few genera of large, showy mosses such as Campylopus, Leucobryum, Macromitrium, Pyrrhobryum and Thuidium. In addition, the hepatic genera Bazzania and Herbertus are frequently collected as 'undetermined mosses'.

The authors initiated an effort to systematically collect from all habitat types on Kaua' $i$, and specifically targeted under-collected areas throughout the island. In this report we list 50 mosses as new for the island of Kaua' $i$ and 16 species represent the first collection for the State of Hawai' $i$. These are indicated by an asterisk (*). In addition, the circumscription of several mosses are now recognized differently from that in either Bartram (1933) or Staples et al. (2004).

With numerous streams, waterfalls and rivers in a tropical climate, it is not surprising that many mosses are rheophytic to aquatic, where they are attached to rocks in swiftly flowing currents. As a percentage of the moss flora, nearly 10 percent of the mosses of Kaua' $i$ are predominantly within riparian habitats where they are either in the splash zone, occasionally inundated, or seasonally submerged. Mosses that are nearly exclusively rheophytic in their ecology or found primarily in similar riparian habitats include: Anomobryum angustirete, Baldwiniella kealeensis, Bryum baldwinii, Donrichardsia bartramii, Ectropothecium zollingeri, Fissidens pacificus, Fissidens grandifrons, Glossadelphus limnobioides, Hageniella micans, Hyophila involuta, Limbella tricostata, Oxyrrhynchium sellaginellifolium, Papillidiopsis aquatica, Philonotis spp. and Phyllodon lingulatus. A large number of these rheophytic species are endemic to the state of Hawai'i which in itself is a fascinating evolutionary research topic to pursue.

Another interesting topic is the distribution of mosses among the Hawaiian Islands. The distance separating Kaua' $\mathrm{i}$ from $\mathrm{O}^{\prime}$ ahu is only 63 air miles, yet 25 species documented from $\mathrm{O}^{\prime}$ ahu have not been located on Kaua' $i$, despite both islands having similar vegetation and elevational range. We are of the opinion that there remains a high probability of encountering these taxa on Kaua' $i$ during future surveys as much of Kaua' $i$ remains inaccessible and many species could occur in exceedingly small micro-environments that are easy to overlook. We also anticipate that with ongoing exploration additional mosses new for the Hawaiian Islands will be discovered. 

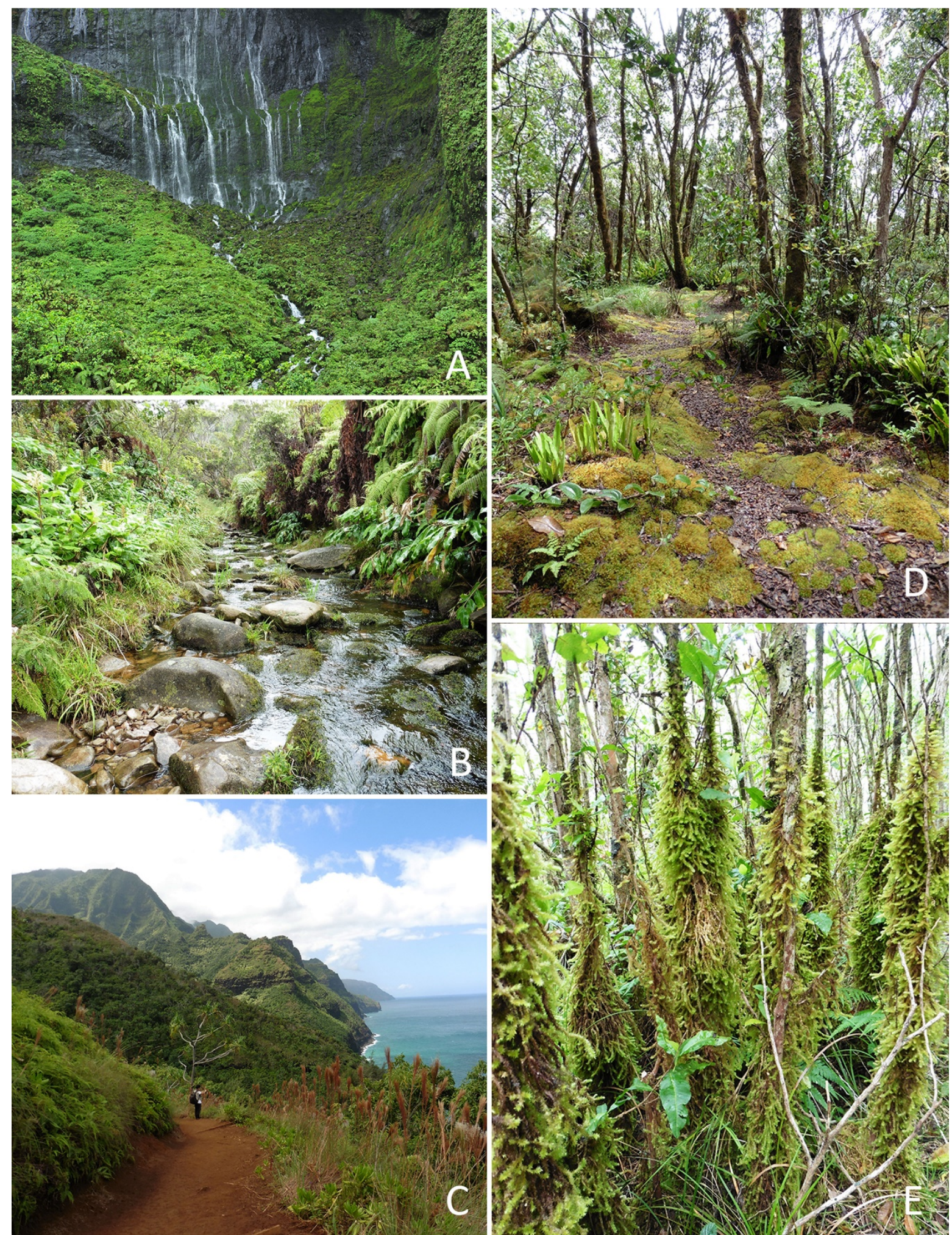

Fig 1: A: Cloud forest habitat dominated by ferns and small statured shrubs at 'Blue Hole', headwaters of the North Fork Wailua River, slopes below Wai'ale'ale. This area is one of the bryological 'hot spots' on Kaua'i and a river system with numerous rheophytes. B: Kawaikōī Stream along Alaka'i Swamp Trail toward Kilohana Vista. Dense mats of the rheophytic Hawaiian endemic Limbella tricostata carpet the stream bed. C: Kalalau Trail along the rugged and scenic Na Pali Coast. D: Metrosideros and Cheirodendron dominated wet forest along Mohihi Trail in the Alaka'i Wilderness Preserve with Dicranum speirophyllum and Leucobryum gracile on forest floor. E: Wet cloud forest habitat with small diameter hardwood trees covered in Aerobryopsis subdiversens ssp. scariosa and Pseudotrachypus wallichii. Photos by the authors. 


\section{CATALOG OF MOSSES}

Species marked with an asterisk are new for the state of Hawai 'i.

Amphidium tortuosum (Hornsch.) Cufod. [Rhabdoweisiaceae]

Specimen examined: HANALEI DisTRICT. Wainiha Stream, headwaters below Hinalele Falls. Common on cliffs, 909 ft., 10 Feb 2015, Wood 16307 (BISH, CAS, NY, PTBG).

The Kaua' $i$ occurrence is much lower in elevation than those populations reported for the islands of Maui and Hawai'i (Staples et. al. 2004).

Aptychella sp. [Pylaisiadelphaceae]

[Mis-applied as Aptychella robusta (Broth.) M.Fleisch. and Clastobryopsis robusta (Broth.) M.Fleisch.]

Specimens examined: LĪHU`E DISTRICT. About the summit ridge of Kawaikini on fine shrub twigs of MetrosiderosCheirodendron wet forest, 5200 ft., 29 Jan 2018, Shevock, Wood \& Ma 51156 (BISH, CAS, HYO, PTBG) and Wood, Shevock \& Ma. 17777 (CAS, PTBG).

For the Hawaiian Islands, a single species of Aptychella as A. robusta was reported by Bartram (1933) as occurring on the islands of Kaua'i and Maui and Staples et al. (2004) referenced this record as Clastobryopsis robusta. This represents the easternmost outpost for the genus Aptychella. When we located Aptychella on the highest slopes of Kaua'i in 2018, a duplicate specimen was sent to Dr. Hiroyuki Akiyama (HYO) who was developing a revision of the genus Aptychella and desired material from the state of Hawai'i for molecular study. The results of the molecular data determined that the Hawaiian plants are not A. robusta, and are actually different from all other members of the genus. Therefore, a new species name was required to recognize this Hawaiian endemic and is being published separately (Akiyama \& Shevock 2019).

\section{*Barbula convoluta Hedw. [Pottiaceae]}

Specimens examined: WAIMEA DISTRICT. Pu'u ka Pele Forest Reserve. Along Waimea River Trail (4WD road) at second river crossing above Wiliwili campsite, 780 ft., 31 Jan 2015, Shevock 46374 (BISH, CAS, PTBG) det. by David Toren.

The only species of Barbula reported previously for the State was B. indica (Hook.) Spreng. Although similar in appearance, these two species are readily distinguished by costal morphology and location and size of gemmae. In B. convoluta, the costa has scattered, hollow or solid papillae, and propagula, when present, are rhizoidal; whereas in $B$. indica, the back of the costa is often rough to mammillose, cells are prorate on both ends, and propagula are often present and axillary.

\section{Barbula indica (Hook.) Spreng. [Pottiaceae]}

Specimens examined: HANALEI District. Na-Pali Coast State Wilderness Park, along the 11 mile Kalalau Trail near the 2 mile marker along Hanakāpī‘ai Stream, 50 ft., 28 Sep 2014, Shevock \& Ma 46053 (BISH, CAS, PTBG); Wainiha, south fork above confluence, 533 m, 19 Jan 2009, Wood 13458 (CAS, PTBG); Powerline Trail (4WD access route), 800 ft., 10 Jan 2015, Shevock 46353 (CAS, KUN, MO, PTBG) confirmed by Richard Zander, along Hanakāpī'ai Stream just below the falls, 775 ft., 28 Jan 2018, Shevock \& Ma 51137 (CAS, PTBG), base of Waiahuakua Falls, 940 ft., 26 Jan 2018, Shevock, Williams, Flynn \& Ma 51050 (CAS, PTBG); KAWAIHAU DisTRICT. Makalela Mountains along Kapahi Stream, 750 ft., 27 Jan 2018, Shevock, Flynn \& Ma 51119 (BISH, CAS, PTBG); LĪHU`E DistRICT. Kaua'i Agro Forest Products LLC, Agroforestry demonstration plot, highway 50, 123 m, 31 Jan 2014, Flynn 7734 (CAS, PTBG), along saddle divide toward Queen Victoria's Profile, Hoary Head Range, 1115 ft., 17 Feb 2016, Shevock, Flynn, Game \& Ma 48074 (CAS, PTBG); WAIMEA DISTRICT. Pu'u ka Pele Forest Reserve, along Kukui Trail in the vicinity of the 1.75 mile marker, on volcanic rock wall, 1500 ft., 31 Jan 2015, Shevock 46368 (CAS, PTBG); Along Koai'e Canyon Trail and Koai'e Stream just above Lonomea Campsite on vertical rock wall above high water zone, $1520 \mathrm{ft}$., $31 \mathrm{Jan}$ 2015, Shevock 46378 (BISH, CAS, F, KUN, MO, NY, PTBG), 1575 ft., 22 Feb 2016, Shevock, Flynn, Game \& Ma 48193 \& 48196 (CAS, PTBG) and 22 Feb 2016, Flynn, Shevock \& Ma 8304 (CAS, HIRO, NY, PTBG, TALL).

Previously reported from the State on O'ahu and Maui (Staples et al. 2004). See discussion on Barbula convoluta above. 


\section{Barbula unguiculata Hedw. [Pottiaceae]}

Specimens examined: HanAlei District. Na Pali-Kona Forest Reserve, headwaters of Kalalau Valley, on volcanic boulder with soil, 4140 ft., 22 Jun 2015, Shevock 46140A (CAS, PTBG); WAIMEA DiSTRICT. Along Camp 10 (Mohihi Road) between YMCA Camp Sloggett and Ditch Trail on vertical volcanic soil bank of road, $3835 \mathrm{ft}$., 22 Jan 2015, Shevock, Flynn, Game \& Nyberg 46170 (BISH, CAS, PTBG).

Specimens labelled as Barbula unguiculata from O'ahu were part of a well distributed set of Bryophyta Hawaiica Exxiccata (Hoe 1978). However, this collection, based on a later reexamination, was more likely to represent Barbula cruegeri Sond. ex Müll. Hal. Therefore, Barbula unguiculata was viewed as misapplied, and subsequently deleted from the Hawaiian moss flora by Staples et al. (2004) and they placed B. cruegeri as a synonym of Barbula indica. Our collections reinstate Barbula unguiculata as part of the Hawaiian moss flora.

\section{Bryum baldwinii Broth. [Bryaceae]}

Specimens examined: KAWAIHAU DISTRICT. Makaleha Mountains, Keālia Forest Reserve, headwaters of Makaleha Stream, 2675 ft., 23 Feb 2016, Shevock, Flynn \& Ma 48233 (CAS) and Ma, Shevock \& Flynn 16-7425 (CAS, KUN).

This is a rheophytic moss that grows in seasonally submerged sites or in splash zones. Based on leaf morphology, this species would most likely be assigned to the genus Imbribryum, but a new name combination has not yet been proposed pending molecular insights to the best generic placement for this beautiful plant. Previously B. baldwinii was known only from the island of Maui (Staples et al. 2004).

*Bucklandiella subsecunda (Hook. \& Grev. ex Harv.) Bedn.-Ochyra \& Ochyra [Grimmiaceae]

[Syn: Racomitrium subsecundum (Hook. \& Grev. ex Harv.) Mitt. \& Wilson]

Specimens examined: LīHU'E DISTRICT. About the summit of Kawaikini in wet litter of boggy areas, 5200 ft., 29 Jan 2018, Shevock, Wood \& Ma 51157 (BISH, CAS, KRAM, PTBG).

The ongoing monographic studies by Halina Bednarek-Ochyra (KRAM) of the various members of Racomitrium s.l. (now recognized as representing five genera) have concluded that many of the collections obtained from the state of Hawai' $i$ named as Racomitrium crispulum are misidentified. Bucklandiella subsecunda is a common and wide-ranging species. Our Kaua'i collection was determined by Halina Bednarek-Ochyra.

\section{Campylopus incurvatus J.-P.Frahm \& Hoe [Dicranaceae]}

Specimens examined: WAIMEA DistRICT. Pihea Trail from Puu O Kila Lookout, 1250 m, 15 Mar 2012, Flynn, Waite, Vernon \& Wood 7522 (CAS, PTBG).

Among the various Campylopus taxa reported from the state of Hawai' $i$, this is the only species not previously reported for the island of Kaua'i. Although several varieties were recognized in Staples et al. (2004), we view these taxa to be quite variable, and therefore, we have taken a more conservative approach. However, future molecular data may either support these varieties or placement at different taxonomic rank.

Chenia leptophylla (Müll.Hal.) R.H.Zander [Pottiaceae]

Syn: Leptophascum leptophyllum (Müll.Hal.) J. Guerra \& M.J. Cano]

Specimens examined: HANELEI DistRICT. Na Pali Coast. Above Hanakāpī‘ai Stream just past junction with the Kalalau Trail, 200 ft., 28 Jan 2018, Shevock \& Ma 51149 (BISH, CAS, PTBG).

This species was obtained from compacted clayey soil in full sun at an emergency heliport landing site. Previously it was known from the island of O'ahu (Staples et al. 2004). The monospecific genus Chenia is a very small terrestrial moss than can easily be overlooked and apparently prefers disturbed sunny soil. 


\section{Claopodium prionophyllum (Müll.Hal.) Broth. [Leskeaceae]}

Specimens examined: HANALEI DiSTRICT. Along Waiahuakua Stream, 800 ft., 26 Jan 2018, Shevock Williams, Flynn and Ma 51064 (CAS, PTBG) and at 400 ft., Shevock, Williams, Flynn \& Ma 51079 (CAS, PTBG).

There seems to be some confusion on the names applied to Hawaiian Claopodium with three species previously reported for the state now placed in synonymy. Two species of Claopodium were recognized in Staples et al. (2004) with the other species, C. whippleanum, similar in appearance. While $C$. whippleanum is generally a soil moss, $C$. prionophyllum seems to prefer boulders. The two species also have a slight difference in coloration where $C$. prionophyllum is generally deeper green.

\section{Ctenidium elegantulum Broth. [Hylocomiaceae]}

Specimens examined: HANELEI DISTRICT. Along Hanakāpī‘ai Stream near the 1.5 mile marker up canyon from junction with the Kalalau Trail at third stream crossing, $700 \mathrm{ft}$., 28 Jan 2018, Shevock \& Ma 51143 (BISH, CAS, KRAM, MO, PTBG); WAIMEA DisTRICT. Off of highway 550 above Awa'awapuhi Stream, 4000 ft., 22 Jan 2015, Shevock, Flynn, Game \& Nyberg 46164 (CAS, PTBG, UC).

This species was previously reported for the islands of $\mathrm{O}^{\prime}$ ahu, Maui and Hawai'i. Although the genus Ctenidium has long been placed in the Hypnaceae, molecular data suggest it is better aligned within the Hylocomiaceae.

\section{Ctenidium stellatulum Mitt. [Hylocomiaceae]}

Specimens examined: HANALEI DiSTRICT. Headwaters of Kalalau Valley, 4140 ft., 22 Jan 2015, Shevock, Flynn, Game \& Nyberg 46157 (CAS, KUN, PTBG, TNS, UC); Limahuli Gardens unit of the National Tropical Botanical Garden, Limahuli Stream below Limahuli Falls, 660 ft., 26 Jan 2015, Shevock, Flynn, Game \& Edmonds 46272 (BISH, CAS, KUN, MO, NY, PTBG, UC).

This species would be viewed as new for the state of Hawai' $i$ since it is not reported in Staples et al. (2004), however, it was reported earlier from the island of O'ahu by Nishimura (1985).

\section{Dicranella hillebrandii (Müll.Hal.) Broth. [Dicranaceae]}

[Syn: Microdus hillebrandii (Müll. Hal.) Paris]

Specimens examined: KAWAIHAU DISTRICT. Along Kuilau Trail at 0.75 mile marker above Keāhua Forestry Arboretum, 800 ft., 27 Sep 2014, Shevock, Ma \& Flynn 46004 (CAS, PTBG); LīHU‘E DistRICT. Hoary Head Range along trail on ridge below Queen Victoria's Profile, $1115 \mathrm{ft} ., 17$ Feb. 2016, Shevock, Flynn, Game \& Ma 48075 (BISH, CAS, KUN, PTBG); WAIMEA DisTRICT. Na Pali Kona Forest Reserve. Along the Pihea Trail less than 1 mile from the Puu O Kila Lookout, 3900 ft., 11 Dec 1996, Shevock 14727 (CAS, PTBG); Kohua Trail to Vista Point off of Mohihi Road at the 2.5 mile trail marker, 3385 ft., 24 Feb 2016, Shevock, Game \& Ma 48245 (CAS); along the Pihea Trail at the 2.25 mile trail marker below junction with Alaka'i Swamp Trail, $3700 \mathrm{ft} ., 20$ Feb 2015, Shevock, Game \& Ma 48175 (CAS, PTBG).

In Staples et al. (2004), this species was reported only for the islands of O`ahu and Maui.

\section{Dicranella integrifolia E.B.Bartr. [Dicranaceae]}

Specimens examined: HANALEI DISTRICT. Powerline Trail on portion of old 4WD road in cut-over forest, $800 \mathrm{ft}$., 30 Jan 2015, Shevock 46351 (BISH, CAS, PTBG) of female plants with capsules and Shevock 46352 (CAS, PTBG) of male plants with antheridial branches; KOLOA DISTRICT. Slopes north of Kalāheo on compacted soil of ridge trail to Kanaele Preserve, 1885ft., 29 Sep 2014, Shevock, Ma \& Flynn 46063 (BISH, CAS, KUN, PTBG); WAIMEA DisTRICT. Along Alaka'i Swamp Trail near trailhead off of Mohihi Road, 3755 ft., 20 Feb 2016, Shevock, Game \& Ma 48153 (CAS) and 48156 (BISH, CAS, MO, NY, PTBG).

Because of its small size, plants of Dicranella are easily overlooked although they can be fairly common on compacted clayey soil especially along trail and road banks in sun. However, sporophytes are nearly always required for proper identification of the five species reported for the State. The male plants look considerably different from female plants when they are intermixed. This species was previously reported from $\mathrm{O}^{\prime}$ ahu, Moloka' $i$, Maui and Hawai' $i$ in Staples et al. (2004). 
Donrichardsia bartramii Huttunen \& Ignatov [Amblystegiaceae]

Misapplied in Hawai'i as Platyhypnidium muelleri (A.Jaeg.) M.Fleisch. (Staples et al. 2004) and Eurhynchium mülleri (A.Jaeg.) E.B.Bartr. (Bartram 1933).

Specimens examined: HANELEI DISTRICT. Along Hanakāp̄̄a ai Stream about 2 miles above Kalalau Trail, 775 ft., 28 Jan 2018, Shevock \& Ma 51134 (CAS, CONN, E, F, KRAM, NY, PTBG, SP) and near the 1.5 mile marker from the Kalalau Trail, 700 ft., 28 Jan 2018, Shevock \& Ma 51140 (BISH, CAS, MO, PTBG, TNS); LīHU`E DISTRICT. At USGS gaging station along North Fork Wailua River, 1200 ft., 18 Feb 2016, Shevock, Flynn, Game \& Ma 48100 (CAS, E, HYO, MO, MW, NY, PTBG, TNS) and headwaters of North Fork Wailua River at Blue Hole, 2400 ft., 19 Feb 2016, Shevock, Flynn, Williams, Game \& Ma 48136 (CAS, PTBG); WAIMEA DisTrict. Kawai' 'iki Canyon below Lonomea Camp, 1463 ft, 22 Feb 2016, Flynn, Shevock, Ma \& Game 8305 (CAS).

This rheophytic Hawaiian moss was originally considered to be Eurhynchium muelleri, a species from New Guinea and Java where the Hawaiian records are the easternmost outpost. Bartram (1933:215) states "although these plants are in most respects similar to E. mülleri of Java, they may, because of the considerably larger and slightly striate leaves, shorter areolation, and the usual minute terminal prickle on the back of the costa, be separable as an insular form." A molecular study conducted by Huttunen and Ignatov (2010) concluded that the Hawaiian plants are not Platyhypnidium muelleri (Brachytheciaceae), but rather, belong to the genus Donrichardsia in the Amblystegiaceae. Therefore, a new name was required to accommodate these Hawaiian plants now viewed as being endemic. The type selected is based on a William Hoe collection obtained from Iao Valley, Maui. Bartram (1933) reported this spectacular rheophytic moss only from Maui (same locality) but it is now documented for all of the major islands except the island of Hawai'i (Staples et al. 2004). Donrichardsia bartramii is a frequently encountered rheophyte preferring fast flowing water and cascades.

\section{Ectropothecium viridifolium E.B.Bartr. [Pylaisiaceae]}

Specimens examined: KAWAIHAU DISTRICT. Along unimproved trail from end of $4 \mathrm{WD}$ road at USGS gaging station of North Fork Wailua River toward Blue Hole, 1295 ft., 28 Jan 2015, Shevock, Flynn \& Williams 46314 (CAS, PTBG).

Although reported for several Hawaiian Islands in Staples et al. (2004), this is the first report for Kaua'i. Ectropothecium remains a very difficult genus with many species poorly understood. Described by Bartram (1933) this species can be separated from other commonly encountered Hawaiian Ectropothecium by the more prominent leaf serrations.

\section{*Fissidens grandifrons Brid. [Fissidentaceae]}

Specimens examined: HANALEI DisTRICT. Na Pali Coast, spray zone of Hanakāpī‘ai Falls, 17 May 2015, Game 15/105 (CAS, UC) and from the same locality, on vertical rock walls of waterfall, 28 Jan 2018, 800 ft., Shevock \& Ma 51127 (BISH, CAS, F, MO, NY, PTBG).

This is a large dark green Fissidens with a multistratose leaf lamina which give the plants a rather stiff texture. The initial Kaua'i collection was smaller and less robust than many specimens studied in herbaria, but the leaf cross sections confirm this species as a new element for the Hawaiian bryoflora. A revisit in 2018 confirmed its presence with more typical sized plants which grew on rock walls with dripping water.

\section{Fissidens hoei Pursell [Fissidentaceae]}

Specimens examined: WAIMEA DISTRICT. Below divide toward Wai'alae Canyon from Nāwaimaka Stream, 3550 ft., 25 Jan 2018, Shevock, Williams, Flynn \& Ma 51036 (CAS).

This Hawaiian endemic was described by Pursell in 1977. It was initially reported only for $\mathrm{O}^{\prime}$ ahu with a single fragmentary stem obtained from the neighboring island of Lana' $i$ (Staples et al. 2004). Many of the smaller species of Fissidens occurring on clayey soil are easily overlooked or less often collected. We anticipate this species will be more common than the herbarium record would suggest. 


\section{Fissidens taxifolius Hedw. [Fissidentaceae]}

Specimens examined: HANALEI DisTRICT. Na Pali Coast State Wilderness, trail in the Honopu area west of highway 550 and north of Awa'awapuhi Trail, 3650 ft., 23 Jan 2015, Shevock, Flynn, Game \& Wood 46211 (CAS, PTBG); Na Pali-Kona Forest Reserve. Awa'awapuhi Valley, 2820-3350 ft., 16 Oct 1991, Flynn, Lorence, Perlman \& Wood 4778 (COLO, MO, PTBG); trail in the Honopu area west of highway 550 and north of Awa'awapuhi Trail, 3950 ft., 23 Jan 2015, Shevock, Flynn, Game \& Wood 46186 (CAS); Hono O Na Pali Natural Area Reserve, Waiahuakua Valley, 100 m, Flynn et al. 8843 (BISH, CAS, PTBG); LİHU`E DISTRICT. Headwaters of North Fork Wailua River at Blue Hole below Wai'ele'ele, 2050 ft., 19 Feb 2016, Shevock, Flynn, Williams, Game \& Ma 48146 (CAS, PTBG); WAIMEA District. Along Nāwaimaka Stream, 3400 ft., 25 Jan 2018, Shevock, Williams, Flynn \& Ma 51028 (CAS, PTBG), Koke'e State Park, along highway 550 along Awa'awapuhi Stream, 4000 ft., Shevock, Flynn, Game \& Nyberg 46158 (CAS, PTBG).

The Flynn et al. 4778 collection was determined by Ronald Pursell. Staples et al. (2004) report this species as only occurring on the islands of $\mathrm{O}^{\prime}$ ahu and Maui. Fissidens taxifolius is likely to be considerably more common in Kaua' $i$ but remains under-collected. Populations are generally on compacted volcanic clayey soil although robust plants from the headwaters of the North Fork Wailua River are on volcanic boulders. Since it was not listed in Bartram (1933) it is most likely to be viewed as a recent introduction that is expanding its range across the state. Of the 12 Hawaiian species of Fissidens, only F. lindbergii Mitt. remains to be discovered on Kaua'i. Another species, F. aphelotaxifolius was listed in Staples et al. (2004) based solely on an immature specimen obtained from Maui (Pursell \& Hoe 1977). However, at that time Pursell was unwilling to add this taxon endemic to the northwestern coast of North America (Pursell 1976) to the Hawaiian bryoflora until additional material became available. No Hawaiian plants we have seen are F. aphelotaxifolius and therefore, we are of the opinion that this species should be excluded from the Hawaiian moss flora.

\section{Floribundaria floribunda (Dozy \& Molk.) M.Fleisch. [Meteoriaceae]}

Specimens examined: HANALEI DistRICT. Hono O Pali Natural Area Reserve, Waiahuakua Valley, 100 m, 26 Jan 2018, Flynn et al. 8841 (BISH, CAS, PTBG); KAWAIHAU DISTRICT. Lìhu'e-Koloa Forest Reserve along unnamed tributary of North Fork Wailua River, 1400-1950 ft., 4 Apr 1991, Flynn, Lorence \& Hanna 4799 (COLO, $\mathrm{MO}, \mathrm{PTBG})$.

Floribundaria is a moss that is frequently pendulous from hardwood branches and twigs. The exceedingly fine branches and golden cast of the plant make it easy to spot in the field. Previous Hawaiian records are for O‘ahu, Maui and Hawai'i (Staples et al. 2004).

\section{Funaria hygrometrica Hedw. [Funariaceae]}

Specimens examined: WAIMEA DISTRICT. Miloli' $i$ Ridge, ca. 4 miles from junction with Makaha Road along boundary between Kui`a NAR and Na Pali-Kona Forest Reserve, 760 m, 24 Nov 2012, Flynn 8003 (BISH, CAS, NY, PTBG).

Among the most common mosses in the world, this species was previously reported by Staples et al. (2004) only for the islands of O'ahu and Hawai ' $\mathrm{i}$. This site was a pine plantation that had recently burned and plants became locally common.

\section{Gemmabryum apiculatum (Schwägr.) J.R.Spence \& H.P.Ramsay [Bryaceae]}

Specimens examined: HANALEI DISTRICT. Along the 11 mile Kalalau Trail of the Na Pali Coast between the 1.75 and 2 mile markers, 235 ft., 28 Sep 2014, Shevock \& Ma 46055 (CAS, PTBG), Powerline Trail along 4WD access paralleling transmission lines, 800 ft., 30 Jan 2015, Shevock 46353A (CAS); KOLOA DiSTRICT. McBryde unit, National Tropical Botanical Garden, Dec 2013, Game 13/111b (CAS); LİHU`E DISTRICT. Kahili Trail toward Kahili Peak above Kahili Mountain Park, 1745 ft., 24 Jan 2015, Shevock, Flynn \& Game 46238 (BISH, CAS, PTBG), off of saddle divide toward Queen Victoria's Profile, $1115 \mathrm{ft} ., 17$ Feb 2016, Shevock, Flynn Game \& Ma 48078 (CAS, PTBG).

In Staples et al. (2004), several Bryum taxa including G. apiculatum are listed as synonyms of Bryum mildeanum Jur. We have not encountered any collections of B. mildeanum from the state of Hawai i. Bryum mildeanum is now placed in the genus Imbribryum. We find little 
evidence to suggest that $G$. apiculatum could be misinterpreted or viewed as Imbribryum mildeanum (Jur.) J.R.Spence; we conclude that this proposed synonymy is perplexing and erroneous. Nonetheless, we have several specimens from Kaua'i of Gemmabryum apiculatum and can reinstate it to the island flora.

\section{*Gemmabryum coronatum (Schwägr.) J.R.Spence \& H.P.Ramsay [Bryaceae]}

Specimens examined: Boundary of HANALEI AND WAIMEA DISTRICTS. Along the 3.25 mile Awa'awapuhi Trail near the 1.75 mile trail marker, 3270 ft., 25 Sep 2014, Shevock, Ma \& Flynn 45977 (CAS, PTBG); KolA DistRICT. Grounds of the National Tropical Botanical Garden, Allerton unit below pump 6, $25 \mathrm{ft}$., 25 Jan 2015, Shevock \& Game 46252 (CAS, PTBG); Lİ̈U'E DisTRICT. Līhu'e, Aukele Street, on soil, 141 ft., 22 Feb 2014, Flynn 7739 (CAS, NY, PTBG) and Flynn 7740 (CAS, PTBG). Determined by David Toren.

Gemmabryum coronatum is a widespread and common pantropical species.

\section{Glossadelphus M.Fleisch. [Hypnaceae]}

The genus Glossadelphus in the state of Hawai' $i$ is basically a group of mosses restricted to or usually in flowing water where they are most often attached to rock surfaces. Many occurrences would be characterized as being semi-rheophytic to rheophytic. Six of the seven species of Glossadelphus in Bartram (1933) are viewed as Hawaiian endemics and Brotherus and Bartram each named three of these new endemic species based on only a few specimens available to them. No members of Glossadelphus were known to occur in Kaua'i and most were known only from their type collection obtained on Maui (Bartram 1933). Buck (1987) determined that Glossadelphus M.Fleisch. (1923), has nomenclatural issues. He transferred some taxa from Glossadelphus into Phyllodon Schimp. (based on an earlier available genus name) and other members of the genus were moved into Taxiphyllum M.Fleisch. Buck (1987) viewed the species of Glossadelphus that he transferred as members of the Hypnaceae versus the Sematophyllaceae. Other species of Glossadelphus, however, have been placed into Taxithelium Mitt. in the Sematophyllaceae. Molecular insights have now transferred Phyllodon to the Symphyodontaceae (Goffinet et al. 2009), and more recently Glossadelphus ogotae Broth \& Yasuda (not yet documented from Kaua'i) was transferred into Filibryum (Kim \& Yamaguchi 2017) a new genus placed in the Hypnaceae. Some of the remaining Hawaiian Glossadelphus may prove to belong here. Staples et al. (2004) mentions the uncertain generic placements for several Hawaiian mosses formerly assigned to Glossadelphus. Since all of our Glossadelphus collections are sterile we are unable to resolve these placements without additional molecular insights. Therefore, in this paper we retain Glossadelphus for those species not transferred by Buck (1987) and that by default remain in the Hypnaceae. Staples et al. (2004) list four species of Glossadelphus, however, none were reported for Kaua'i and a fifth species, Glossadelphus baldwinii Broth. was transferred along with G. laevifolius to Taxiphyllum laevifolium (Mitt.) W.R.Buck. See our entry below under Phyllodon for additional information regarding this moss and our different conclusion. Staples et al. (2004) also placed Glossadelphus chryosbasilaris Broth. as a synonym of Glossadelphus ogatae following the treatment presented by Tixier (1988). However, we view this species as distinct from G. ogatae. Tixier (1988) apparently was either unaware or lacked specimens of Glossadelphus acutifolius E.B. Bartr. and G. limnobioides Broth., both described as Hawaiian endemics, since they are not referenced in his monograph. The Glossadelphus species endemic in Hawai'i would be very good candidates for a molecular study to determine their generic and family placement.

\section{Glossadelphus acutifolius E.B.Bartr. [Hypnaceae]}

Specimens examined: KAWAIHAU DISTRICT. At end of Kuilau Trail about 2 miles above Keāhua Forestry Arboretum and at the beginning of the Moalepe Trail, $1140 \mathrm{ft}$., 27 Sep 2014, Shevock, Ma \& Flynn 46011 (CAS, PTBG).

Bartram described this species in 1933. 


\section{Glossadelphus chrysobasilaris Broth. [Hypnaceae]}

Specimens examined: KAWAIHAU DISTRICT. Along unimproved trail from end of 4 WD road at USGS gaging station of North Fork Wailua River to Blue Hole, slopes below Wai'ale'ale, $1300 \mathrm{ft}$., 28 Jan 2015, Shevock, Flynn \& Williams 46302 (CAS, PTBG).

\section{Glossadelphus limnobioides Broth. [Hypnaceae]}

Specimens examined: HANALEI DiSTRICT. Below waterfall of Waiahuakua Stream, $800 \mathrm{ft}$., 26 Jan 2018 , Shevock, Williams, Flynn \& Ma 51062 (CAS, PTBG) and 51066 (BISH, CAS, E, KRAM, MO, NY, PTBG, SP), Hanakāpī'ai Stream just below the falls about 2 miles from junction with Kalalau Trail, 775 ft., 28 Jan 2018 , Shevock \& Ma 51135 (BISH, CAS, MO, NY, PTBG); KAWAIHAU DISTRICT. Along unimproved trail from end of 4 WD road at USGS gaging station of North Fork Wailua River, to Blue Hole, slopes below Wai'ale'ale, $1300 \mathrm{ft}$., 28 Jan 2015, Shevock, Flynn \& Williams 46316 (BISH, CAS, KRAM, KUN, MO, NY, PTBG) and Flynn, Shevock \& Williams 8107 (CAS, PTBG), Makalela Mountains, Kapahi Stream, 650 ft., 27 Jan 2018, Shevock, Flynn \& Ma (CAS, PTBG) and 51104 (BISH, CAS, PTBG); LİHU`E DISTRICT. Kahili Road below Kahili Mountain Park in small stream, 660 ft., 24 Jan 2015, Shevock, Flynn \& Game 46241 (CAS, PTBG).

\section{Grimmia longirostris Hook. [Grimmiaceae]}

Specimens examined: HANALEI DisTRICT. Kalalau Valley, open SE slope over lichen-covered volcanic boulders, 925-1065 ft., 6 Mar 1991, Flynn, Lorence \& Wood 4464 (AD, COLO, PTBG); WAIMEA DisTRICT. Po'omau Canyon, 1400 ft., 19 Jan 1993, Flynn, Perlman \& Wood 5202 (COLO, NY, PTBG).

The discovery of the genus Grimmia on Kaua'i is noteworthy. Most Grimmia found in the state are located at considerably higher elevations on the islands of Maui and Hawai' $i$ where temperatures are colder. Of the seven Grimmia species reported for the State, only G. longirostris matches this material although the capsules on Flynn, Lorence \& Wood 4464 are immature. Grimmia longirostris is variable and one of the most common species in the genus with a wide geographic range on several continents.

\section{Haplocladium microphyllum (Hedw.) Broth. [Leskeaceae]}

Specimens examined: KolOA DISTRICT. Headquarters of the National Tropical Botanical Garden, Crum Cottage, 124 m, 13 Oct 2010, M. Waite s.n. (PTBG 060228), National Tropical Botanical Garden greenhouse, 13 Oct 2010, M. Waite s.n. (PTBG 060229), Koloa, farm of David Boucher, 5 Mar 2014, Flynn \& Boucher 7756 (CAS, PTBG).

Determined by Mashuri Waite and David Toren. This is a widespread species previously reported for the state of Hawai' $\mathrm{i}$ only from the island of O'ahu (Staples et al. 2004). It is probably a recently introduced species and likely to remain restricted to anthropogenic sites.

\section{Heterophyllium subauriculatum (Müll.Hal.) Broth. [Sematophyllaceae]}

Specimens examined: KAWAIHAU DiSTRICT. Slopes at edge of Moloa'a Forest Reserve, $450 \mathrm{ft.}, 24$ Jan 2018 , Shevock, Flynn, Williams \& Ma 50979 (CAS, PTBG).

This species was reported by Staples et al. (2004) only for the islands of Maui and Hawai' $i$. The Kaua'i occurrence is mixed with Sematophyllum subpinnatum, and when grown together they can be similar in appearance. Heterophyllium subauriculatum has coarsely serrated leaf apices which will easily distinguish it from Sematophyllum species.

\section{Hookeria acutifolia Hook. \& Grev. [Hookeriaceae]}

Specimens examined: KAWAIHAU DISTRICT. Līhu'e-Koloa Forest Reserve. Slopes above the North Fork Wailua River between end of 4WD drive road at USGS gauging station and Blue Hole, 1360 ft., 28 Jan 2015 , Shevock, Flynn \& Williams 46308 (BISH, CAS, KUN, MO, PTBG); KolOA District. Līhu'e-Koloa Forest Reserve, mountains north of Wahiawa Bog [Kanaele], north fork of Wahiawa Stream, 650-710m, 7 Apr 1988, Lorence, Flynn, Wagner \& Imada. 5936 (COLO, Hoe Herb., PTBG), Wahiawa drainage, 2200-2400 ft., 7 Feb 1991, Flynn, Lorence, Wood \& Perlman 4426 (COLO, PTBG).

Although new for Kaua' $i$, this warm-temperate and tropical species may actually prove to be relatively common in wet, humid sites in partial shade. The gemmae borne on the leaf tips 
of this delicate species are highly diagnostic. It was previously known from $\mathrm{O}^{`}$ ahu, Lana'i, Maui and Hawai'i (Staples et al. 2004).

\section{*Imbribryum sp. [Bryaceae]}

Specimens examined: Boundary of LīHU`E AND KAWAIHAU DisTRICTS. Līhu'e-Koloa Forest Reserve. Headwaters of the North Fork Wailua River on dripping wet rock faces, 600-670 m, 23 Aug 1990, Flynn, Lorence, Kiehn \& Gustafson $4212 b$ (CAS, COLO, PTBG).

This specimen was originally considered to be closest to Bryum cf. baldwinii [=Pohlia b.] as determined by W.A. Weber in 1991. However, the plants have leaves with a rounded apex and laminal cells large and thin-walled with a narrow, weak border. Initially we thought this plant could represent Plagiobryoides cellularis (Hook.) J.R.Spence. This species, previously known as Bryum cellulare, occurs widely throughout the tropics. Unfortunately, the Kaua' $i$ collection is sterile. Examined material of the Hawaiian species Bryum megalostegium Sull., considered a synonym of Gemmabryum apiculatum, is similar to the specimen, but is much smaller and produces rhizoidal tubers. After careful review, Spence determined this plant is likely to represent an undescribed species of Imbribryum, even though it superficially resembles Plagiobryoides cellularis. Additional field work remains with the hope of finding this species with sporophytes. Molecular data is also needed to assist in determining the best generic placement for this species. At some point this new species will be described.

\section{Insomniella plumiformis (Wilson) Hedenäs, Schlesak \& D.Quandt [Pylaisiaceae]}

[Syn: Hypnum plumaeforme Wilson]

Specimens examined: HANALEI DISTRICT. Powerline Trail in secondary forest, $1490 \mathrm{ft} ., 30$ Jan 2015, Shevock 46357 (BISH, CAS, PTBG); KAWAIHAU DISTRICT. Along unnamed tributary of North Fork Wailua River, 1001940 ft., 4 Sep 1991, Flynn, Lorence \& Hanna 4798 (COLO, HIRO, PTBG); KolOA District. Pu'ulima Road, Kalaheo. A roadside lawn weed, 335 m, 10 Jan 2012, Flynn 7501 (PTBG); LīHU`E District. Kaua'i Agro Forest Products LLC, Agroforestry demonstration plot along highway 50 E of Kaua'i Humane Society, 31 Jan 2014, Flynn 7731 (BISH, CAS, HIRO, MO, NY, PTBG, TALL); WAIMEA DISTRICT. Na Pali-Kona Forest Reserve, along Pihea Trail, 3900 ft., 11 Dec 1996, Shevock 14740 (CAS, PTBG), Pu'u O Kila Lookout, grassy area about platform, 4170 ft., 11 Dec 1996, Shevock 14745 (BISH, CAS, PTBG), 15 Mar 2012, Flynn, Waite, Vernon \& Wood 7510 (CAS, PTBG); along Alaka'i Swamp Trail to Kilohana Vista, 4070 ft., 20 Feb 2016, Shevock, Game \& Ma 48171 (CAS, MO, PTBG, TNS), Koke'e State Park, Berry Flat Trail off Camp 10 Road, 6 May 2014, Tangalin \& DeMotta 3778 (CAS, PTBG, TALL).

This Asian species is clearly becoming the most invasive moss in Hawai ' 1 . For decades this moss has been known by the name Hypnum plumaeforme. Based on the Melbourne Code the spelling of this moss was changed to Hypnum plumiforme and based on a recent molecular paper (Schlesak et al. 2018), this moss is now transferred into a new genus as Insomniella. 'Hypnum plumaeforme' was not reported for the Hawaiian Islands by Bartram (1933, 1939), and the first record of this species for the island of Hawai' $i$ is based on collections obtained in 1955 (Hoe 1974). Staples et al. (2004) only added this species as new for the island of Maui. However, collections on Kaua'i from the early to mid-1990s (listed above) indicate that this species was already common at that time. It is surprising that such a large, mat-forming moss would not have been collected previously unless it was misinterpreted as a robust Ectropothecium or Vesicularia. If I. plumiformis did arrive in Kaua'i only in the past 70 years then it has spread into wet rain forest habitats rather quickly where it is now a common moss on the forest floor, especially in the Alaka'i Swamp region. Hypnum plumiforme has long been viewed as an aggressive introduced species on the Big Island (Waite 2007).

\section{Leucoloma scaberulum E.B.Bartr. [Dicranaceae]}

Specimens examined: HANALEI District. Hono O Na Pali Natural Nature Reserve. Below falls of Waiahuakua Stream, 480 ft., 20 Jan 2018, Shevock, Williams, Flynn \& Ma 51085 (ALTA, CAS); KolOA DISTRICT. Līhu'e-Koloa Forest Reserve, along Wahiawa Stream, 700 m, 18 Dec 1990, Flynn, Lorence, Ragone \& Wood 4335 
(AD, COLO, PTBG) WAIMEA District. Na Pali-Kona Forest Reserve. Alaka`i Swamp Trail at Kawaikō̄ Stream, $3790 \mathrm{ft}$., 24 Sep 2014, Shevock, Ma \& Flynn 45932 (ALTA, CAS, PTBG).

This collection was originally named Dicranoloma cf. gracile Broth. ex E.B.Bartr. by W.A. Weber in 1991 then annotated as Leucoloma molle (Müll.Hal.) Mitt. by Mashuri Waite in 2012. The papillose cells commonly observed at the leaf apex along with a broad border of clearcolored linear cells from middle to base aid in the identification of this species. The monographic work on the genus Leucoloma by La Farge (2002) was not referenced in Staples et al. (2004), and therefore, a different assessment of Leucoloma species are reported for Hawai' $i$ including the removal of $L$. molle and the resurrection of L. hawaiiense Broth. that was placed in synonymy with L. molle by Bartram (1933). No species of Leucoloma were reported as occurring on Kaua'i by Staples et al. (2004). Leucoloma scaberulum was not reported in Bartram (1933); it was described six years later (Bartram 1939). In Staples et al. (2004) L. scaberulum was only reported for the island of $\mathrm{O}^{`}$ ahu. Our collections were confirmed by Catherine La Farge (ALTA).

\section{Orthotrichum diaphanum Brid. [Orthotrichaceae]}

Specimens examined: WAIMEA DistRICT. Pu'u ka Pele Forest Reserve. Along Kukui Trail from highway 550 to Waimea River between the 1.75 and 2.0 mile trail marker, $1075 \mathrm{ft}$., 31 Jan 2015, Shevock 46369 (CAS, PTBG).

This species is easy to recognize since it is the only member of this genus with conspicuous hair points. However, plants can occur in such small tufts that it can be easily overlooked among other mosses. The Waimea occurrence of Orthotrichum diaphanum occurs as isolated tufts among extensive populations of Fabronia nietneri Müll.Hal. Orthotrichum diaphanum is likely to be found in other drier hardwood forests within the Waimea Canyon. Staples et al. (2004) lists Hawaiian records only for the islands of Hawai' $i$ and Maui.

\section{*Papillidiopsis aquatica (Dixon) B.-C.Ho \& B.C.Tan [Sematophyllaceae]}

Specimens examined: KAWAIHAU DISTRICT. Along unimproved trail from end of 4 WD road at USGS gaging station to Blue Hole, North Fork Wailua River, 1295 ft., 28 Jan 2015, Shevock, Flynn \& Williams 46313 (BISH, CAS, PTBG, UC) and 18 Feb 2016, 1350 ft., Shevock, Flynn, Game \& Ma 48116 (CAS, F, HYO, KRAM, KUN, MO, NY, PTBG, UC).

This species is widely scattered across Malesia and its presence in the Hawaiian Island group is not surprising. The strongly concave leaves with a markedly constricted leaf acumen and the weakly papillose to entirely smooth leaf areolation help to identify this species from its closest ally, P. ramulina (Thwaites \& Mitt.) W.R.Buck \& B.C.Tan. The preferred habitat of $P$. aquatica on rocks and boulders in shaded streams also helps to separate the two taxa. Papillidiopsis aquatica was at one time considered a synonym of $P$. ramulina. See Ho and Tan (2002) for a review of the history of this species.

\section{*Papillidiopsis ramulina (Thwaites \& Mitt.) W.R.Buck \& B.C.Tan [Sematophyllaceae]}

Specimens examined: KAWAIHAU DISTRICT. Along 4WD road just before reaching the USGS gaging station, North Fork Wailua River, 1200 ft., 18 Feb 2015, Shevock, Flynn, Game \& Ma 48099 (BISH, CAS, PTBG).

See discussion regarding $P$. aquatica above.

\section{Philonotis hastata (Duby) Wijk \& Margad. [Bartramiaceae]}

Specimens examined: HANALEI DiSTRICT. South fork Wainiha Valley to right of Wainiha River (facing mauka), 771 m, 5 Apr 2016, Deans 140 (CAS, PTBG); WAIMEA DisTRICT. Along Cliff Trail at Koke“e Stream, 3145 ft., 29 Jan 3025, Shevock 46325 (BISH, CAS, PTBG).

These collections were attached to seasonally submerged volcanic rock-slabs and boulders. Staples et al. (2004) reported this species from O`ahu, Maui and Hawai ‘i. 
Phyllodon lingulatus (Cardot) W.R.Buck [Symphyodontaceae]

[Syn: Glossadelphus baldwinii Broth.]

Specimens examined: HanAlei DisTrict. Na Pali Coast State Wilderness Park, along the 11 km mile Kalalau Trail of the Na Pali coast near the 1.5 mile marker, $350 \mathrm{ft}$., 28 Sep 2014, on volcanic boulders in splash zone of stream, Shevock \& Ma 46049 (CAS, KUN, MO, NY, PTBG), Limahuli Gardens unit of the National Tropical Botanical Garden, on rocks in Limahuli Stream, 500 ft., 26 Jan 2015, Shevock, Flynn, Game \& Edmonds 46268 (CAS, PTBG), Waiahuakua Stream near base of waterfall, 940 ft., 26 Jan 2018, Shevock, Williams, Flynn \& Ma 51054 (BISH, CAS, MO, NY, PTBG); KAWAIHAU DISTRICT. Keālia Forest Reserve, at the end of Kuilau Trail, in Uhau'iole Stream, 1080 ft., 27 Sept 2014, on rock, Ma, Shevock \& Flynn 14-5973 (CAS, UC).

In our view, Glossadelphus baldwinii was incorrectly placed into synonymy with Glossadelphus laevifolius (Mitt.) E.B.Bartr. by Tixier (1988). The two species differ in their leaf marginal serration, which is strongly bigeminate in G. baldwinii and only singly toothed, or at times weakly bifid, in G. laevifolius. The laminal cells of G. baldwinii are strongly prorate at both ends, while those of G. laevifolius are smooth. A comparison of the illustrations of the former species in Bartram (1933, fig. 179) and the latter in Sharp et al. (1994, fig. 747, c-e) will clarify the confusion made by Tixier (1988) regarding these two taxa. In Staples et al. (2004), the authors chose to follow the synonymy of Tixier (1988). Glossadelphus laevifolius was viewed by Buck (1987) to represent a species of Taxiphyllum and a new combination was proposed as Taxiphyllum laevifolium (Mitt.) W.R.Buck. Staples et al. (2004) applied that circumscription in the updated checklist. While G. baldwinii in our opinion is not a synonym of G. laevifolius, it can be comfortably synonymized with Phyllodon lingulatus. Again, a comparison of the species descriptions and illustrations of these two species published in Bartram (1933, for G. baldwinii) and Noguchi (1994, for Glossadelphus lingulatus) support our taxonomic conclusion proposed here. As a new genus name for the Hawaiian island group, Phyllodon lingulatus is a widespread species occurring in Taiwan, Japan, Vietnam, Philippines and Indonesia. This species seems to prefer wet rocks.

\section{*Physcomitrium eurystomum Sendtn. [Funariaceae]}

Specimens examined: KAWAIHAU DISTRICT. CTAHR station off highway 550, upper Wailua, $164 \mathrm{~m}, 18 \mathrm{Apr}$ 2017, Flynn 8728 (CAS, PTBG).

A rather widespread species in Asia, this richly fruiting collection was made in a cultivated setting on nylon shade cloth of a greenhouse and we consider it likely to become an adventive component of the Hawaiian moss flora. Exactly when this species was introduced to Kaua' $i$ is unclear.

\section{*Plagiobryoides sp. [Bryaceae]}

Specimens examined: KAWAIHAU DISTRICT. CTAHR station off highway 550, upper Wailua, $163 \mathrm{~m}, 18 \mathrm{Apr}$ 2017, Flynn 8728 (CAS, PTBG).

This collection was made in a cultivated setting on a greenhouse weed mat floor and is likely to be another moss that could possibly expand beyond its initial occurrence and become an escaped exotic component of the Hawaiian moss flora. At this time we have not been able to determine the species name to apply to this collection.

\section{*Pseudotaxiphyllum distichaceum (Mitt.) Z.Iwats. [Hypnaceae]}

Specimens examined: WAIMEA DISTRICT. Na Pali-Kona Forest Reserve, along Pihea Trail less than 1 mile from Pu'u O Kila Lookout, 3900 ft., 11 Dec 1996, Shevock 14736 (CAS, NY, PTBG); Pihea Trail near junction with Alaka'i Swamp Trail, 4150 ft., 24 Sep 2014, Shevock, Ma \& Flynn 45926 (CAS, MO, PTBG) \& 46928 (BISH, CAS, DUKE, F, KRAM, KUN, NY, PTBG, TNS), along Nāwaimaka Stream, 3400 ft., 25 Jan 2018, Shevock, Williams, Flynn \& Ma 51026 (CAS).

The only record of the genus Pseudotaxiphyllum reported for Hawai'i is P. elegans (Brid.) Z.Iwats. that was collected from Maui and listed under its previous name Isopterygium elegans (Brid.) Lindb. (Hoe 1979; Staples et al. 2004). These two specimens, Vitt 14852 \& 14890 
(ALTA) determined by Hoe in 1978 should be re-examined to confirm the identifications. Pseudotaxiphyllum distichaceum has a wide distribution range from eastern North America to South America and Asia. Although easily confused with P. elegans, it differs in having asymmetric, often cultriform leaves, and twisted vermiform gemmae in dense clusters generally appearing at leaf apices. These features should readily distinguish $P$. distichaceum from all other Hawaiian mosses. See also Ireland (2014) for species descriptions and illustrations.

\section{*Ptychostomum creberrimum (Taylor) J.R.Spence \& H.P.Ramsay [Bryaceae]}

Specimens examined: Koloa DistRICT. Līhu'e-Koloa Forest Reserve, ridge ESE of Pu'u Kolo, 6 Sep 1990, Flynn \& Kiehn 4224 (COLO, Hoe Herb., MO, PTBG) determined by David Toren.

This collection has been attributed to different taxa. The most recent annotation applied to this collection is Bryum caespiticium Hedw., a dioicous species, but this plant is actually synoicous.

\section{*Radulina laevihamata (Dixon) B.C.Tan, T.J.Kop. \& D.H.Norris [Sematophyllaceae]}

Specimens examined: Boundary of HANALEI AND WAIMEA DISTRICTS. Awa'awapuhi Trail near trail marker 0.25, 4060 ft., 25 Sep 2014, Shevock, Ma \& Flynn 45961A (CAS, UC); KOLOA DiSTRICT. Slopes north of Kalāheo toward Kanaele Preserve, 2135 ft., 29 Sep 2014, Shevock, Ma \& Flynn 46083A (CAS, PTBG).

\section{*Rhytidiadelphus squarrosus (Hedw.) Warnst. [Hylocomiaceae]}

Specimens examined: WAIMEA DisTRICT. Pu'u O Kila Lookout along path from parking lot to lookout platform, 1268 m, 12 Mar 2012, Flynn et al. 7509 (PTBG).

This species was first noticed and identified by Mashuri Waite and is apparently a recent introduction although a cursory search at this locality during January 2015 failed to relocate it. Rhytidiadelphus squarrosus can become a lawn weed when climatic conditions are favorable and can colonize roadsides where grasses and other herbaceous vegetation are periodically mowed. Considering the number of people who visit annually to the $\mathrm{Pu}^{\prime} \mathrm{u}$ O Kila Lookout and surrounding habitat within moist cloud forest environments, one would expect introduced mosses to appear periodically at this location but hopefully not persist.

\section{*Sematophyllum subhumile (Müll.Hal.) M.Fleisch. [Sematophyllaceae]}

Specimens examined: Hanalei District. Powerline Trail along rough 4WD road and trail paralleling powerline transmission corridor along ridge, 1075 ft., 30 Jan 2015, Shevock 46358 (CAS, PTBG), Hanakāpī'ai Stream near the 1.5 mile trail marker above Kalahau Trail, 700 ft., 28 Jan 2018, Shevock \& Ma 51142 (CAS, PTBG); KAIWAIHAU District. Makalela Mountains along Kapahi Stream, 650 ft., 27 Jan 2018, Shevock, Flynn \& Ma 51099 (CAS, PTBG); WAIMEA DiSTRICT. Koke'e State Park, Halemanu-Koke‘e Trail, 3757 ft., 5 Mar 2014, Flynn \& Boucher 7745 (BISH, CAS, HIRO, NY, PTBG, TALL).

Sematophyllum subhumile and S. subpinnatum (Brid.) E. Britton are the two most widespread species of the genus in Asia and Australasia. Their distribution reaching the Hawaiian Islands in the Pacific Ocean is to be expected. The two species differ in the length of leaf apical cells which are oval to rhomboidal in S. subpinnatum and oblong to elongate in $S$. subhumile. Good illustrations of the differences in plant morphology between the two taxa are presented in Ramsay et al. (2002).

*Sematophyllum subhumile (Müll.Hal.) M.Fleisch. var. contiguum B.C.Tan, Schofield \& H.P.Ramsay [Sematophyllaceae]

Specimens examined: HANALEI DISTRICT. Trail in the Honopu area west of highway 550 and north of the Awa'awapuhi Trail, 3700 ft., 23 Jan 2015, Shevock, Flynn, Game \& Wood 46205 (CAS, PTBG, UC); boundary of HANELEI AND WAIMEA DISTRICTS. Along Awa'awapuhi Trail near the 0.75 mile marker, 25 Sep 2014, Shevock, Ma \& Flynn 45973 (CAS, PTBG, UC); WAIMEA DISTRICT. Along Kukui Trail from highway 550 to Waimea River in vicinity of the 1.75 mile marker, $1500 \mathrm{ft}$., 31 Jan 2015, Shevock 46366 (BISH, CAS, PTBG, UC). 
The var. contiguum differs mainly from the var. subhumile in having somewhat narrower, longer more acuminate leaf apices. See Ramsay et al. (2002) for other morphological differences between the two varieties and the list of synonyms placed under var. contiguum. The var. contiguum appears to be widespread in Australasia reaching Oceania in distribution.

\section{Sematophyllum subpinnatum (Brid.) E.Britton [Sematophyllaceae]}

Specimens examined: HANALEI DisTRICT. Along highway 56 at Manihiholo Dry Cave, Ha'ena, 15 ft., 30 Jan 2015, Shevock 46362 (BISH, CAS); Limahuli Gardens unit of the National Tropical Botanical Garden, $350 \mathrm{ft} ., 26$ Jan 2015, Shevock, Flynn, Game \& Edmonds 46259 (CAS, PTBG); along the 11 mile Kalalau Trail of the Na Pali Coast between the 0.5 and 1 mile marker, 560 ft., 28 Sept 2014, Shevock \& Ma 46031 (CAS, KUN, PTBG), Waiahuakua Stream below waterfall, 940 ft., 26 Jan 2018, Shevock, Williams, Flynn \& Ma 51048 (CAS, MO, PTBG, SP) and at $800 \mathrm{ft}$., 51069 (CAS, MEXU, PTBG); Hono O Pali Natural Area Reserve, Waiahuakua Valley, 320 m, 26 Jan 2018, Flynn et al. 8820 (BISH, CAS, PTBG); KAWAIHAU DisTRICT. Keāhua Forestry Arboretum area along Uhau'iole Stream, 565 ft., 27 Sep 2014, Shevock, Ma \& Flynn 45990 (CAS, KUN, PTBG), Moloa'a Forest Reserve above highway 56, $450 \mathrm{ft}$., 24 Jan 2018, Shevock, Flynn, Williams \& Ma 50979a (CAS) and at 700 ft., 50992 (CAS); KolOA District. Kalāheo. National Tropical Botanical Garden, McBryde unit, 40 ft., 17 Feb 2016, Shevock, Game \& Ma 48061 (CAS, PTBG), along Papalina Road near entrance to National Tropical Botanical Garden, 595 ft., Shevock \& Ma 50997 (CAS, PTBG), National Tropical Botanical Garden headquarters site, 381 ft., 12 Jan 2012, Flynn \& Vernon 7504 (CAS, HIRO, PTBG, TALL), 13 Oct 2010, Waite s.n. (PTBG) and 13 Oct 2010, Lorence \& Waite 10232 (MO, PTBG, US); LİHU`E DISTRICT. Along ridge toward Victoria’s Profile, $1115 \mathrm{ft}$., Shevock, Flynn, Game \& Ma 48081 (CAS, PTBG) and road on slope of saddle divide between Queen Victoria's Profile and Hokulei Peak, 725 ft., 17 Feb 2016, Shevock, Flynn, Game \& Ma 48088 (CAS).

This species was reported only for the islands of $\mathrm{O}^{`}$ ahu and Hawai'i by Staples et al. (2004). Based on our collections, it is relatively widespread across Kaua'i, especially in low elevations along with the form tristiculum (Mitt.) B.C.Tan \& Y.Jia discussed below. Common substrates include palm trunks, Pandanus and Schefflera.

*Sematophyllum subpinnatum (Brid.) E.Britton fo. tristiculum (Mitt.) B.C.Tan \& Y.Jia [Sematophyllaceae]

[Synonym: Sematophyllum tristiculum (Mitt.) A.Jaeg.]

Specimens examined: HANALEI DistRICT. Along the 11 mile Kalalau Trail of the Na Pali Coast between 0.5 and the 1 mile trail marker, $500 \mathrm{ft} ., 28$ Sep 2014, Shevock \& Ma 46037 (CAS, PTBG); KAWAIHAU DiSTRICT. Keālia Forest Reserve, along the Kuilau Tail at the 0.5 mile marker above the Keāhua Forestry Arboretum, $600 \mathrm{ft}$., $27 \mathrm{Sep}$ 2014, Shevock, Ma \& Flynn 46000A (CAS, PTBG); KolOA DisTRICT. Kalāheo. National Tropical Botanical Garden, headquarters, patio of Education Center. Growing on trunk of Erythrina crista-galli, 135 m, 13 Oct 2010, Lorence 10232 (MO, PTBG, US); McBryde unit, 40 ft., 23 Sep 2014, Shevock \& Ma 45896 (BISH, CAS, PTBG) \& 45899 (CAS, PTBG) and Allerton unit across from pump 6, 25 ft., 25 Jan 2015, Shevock \& Game 46247 (CAS, PTBG, UC), Kalāheo, Puulima Road on electrical junction box, 1076 ft., 13 Jan 2014, Flynn 7721 (BISH, CAS, HIRO, PTBG, TALL); LīHU'E DISTRICT. Kahili Peak on steep narrow ridge above Kahili Mountain Park, $2225 \mathrm{ft}$. , 24 Jan 2015, Shevock, Flynn \& Game 46235 (CAS, PTBG).

The broadly defined lamina and a broadly acute to nearly round leaf apex makes this an easily recognized form of $S$. subpinnatum. Plants with intermediate leaf forms in transition from fo. tristiculum to fo. subpinnatum can be observed. Although this was earlier recognized as a species and then later considered only worthy of varietal recognition, observation of the co-existence of the "tristiculum" and "subpinnatum" leaf form in a number of populations in Malesia determined the form rank to be more appropriate.

\section{Syrrhopodon armatus Mitt. [Calymperaceae]}

Specimens examined: KAWAIHAU DISTRICT. Moalepe Trail beyond junction with Kuilau Trail above Keāhua Forestry Arboretum, 1175 ft., 27 Sep 2014, Shevock, Ma \& Flynn 46015 (CAS, PTBG); KolOA DisTRICT. Slopes north of Kalāheo on ridge trial (old abandoned road) to Kanaele Preserve, $1200 \mathrm{ft} ., 29$ Sep 2014, Shevock, Ma \& Flynn 46059 (BISH, CAS, PTBG).

Of the four species of Syrrhopodon reported for the state in Staples et al. (2004), only S. hawaiicus Müll.Hal. was previously reported to occur on Kaua'i. 


\section{Syrrhopodon semiliber (Mitt.) Besch. [Calymperaceae]}

Specimens examined: KAWAIHAU DISTRICT. Līhu'e-Koloa Forest Reserve. Slopes above the North Fork Wailua River between end of 4WD drive road at USGS gauging station toward Blue Hole, $1300 \mathrm{ft}$., 28 Jan 2015 , Shevock, Flynn \& Williams 46317 (CAS, PTBG); Moalepe Trail beyond junction with Kuilau Trail above Keāhua Forestry Arboretum, 1180 ft., 27 Sep 2014, Shevock, Ma \& Flynn 46019 (CAS).

This easily overlooked species was discovered growing on fine twigs of Clidemia (Melastomataceae) mixed with Daltonia and also on Hibiscus branches. However, the filiform gemmae forming thick mats along the costa at the mid-section of the leaf are highly diagnostic. Syrrhopodon semiliber is widespread in tropical regions but is infrequently collected. It was previously reported for both O'ahu and Hawai'i (Staples et al. 2004).

\section{Taxithelium mundulum (Sull.) E.B.Bartr. [Sematophyllaceae]}

[Syn. Sematophyllum mundulum (Sull.) P. Câmara]

Specimens examined: HANALEI DISTRICT. Trail in the Honopu area west of Highway 550 and north of Awa'awapuhi Trail, 3650 ft., 23 Jan 2015, Shevock, Flynn, Game \& Wood 46219 (CAS, PTBG), Limahuli Valley in valley bottom, 250-750 ft., 28 Dec 1990, Flynn, Bates, Plews \& Wichman 4354 (AD, COLO, Hoe herb., PTBG); KAIWAIHAU DistRICT. Kapahi Stream, base of Makalela Mountains above Kapa'a Homesteads, $750 \mathrm{ft} ., 27 \mathrm{Jan}$ 2018, Shevock, Flynn \& Ma 51118 (CAS, PTBG); KolOA DisTRICT. Kahili Mountain Park, 640-680 ft., 30 Sep 1991, Flynn, Montalvo, Hanna \& Cooney 4737 (COLO, PTBG, TALL); WAIMEA District. Along Camp 10 (Mohihi Road) between YMCA Camp Sloggett and Ditch Trail, in mixed forest on base of large Metrosideros trunk in sun, 3835 ft., 22 Jan 2015, Shevock, Flynn, Game \& Nyberg 46165 (CAS, UC), Kohua Trail to Vista Point, 3730 ft., 24 Feb 2016, Shevock, Flynn, Wood \& Ma 48251 (CAS, PTBG), along Nāwaimaka Stream, 3400 ft., 25 Jan 2018, Shevock, Williams, Flynn \& Ma 51017 (CAS, PTBG), below divide toward Wai'alae Canyon from Nāwaimaka Stream, 3550 ft., 25 Jan 2018, Shevock, Williams, Flynn \& Ma 51034 (BISH, CAS, F, MO, NY, PTBG).

Bartram (1933) described Taxithelium mundulum as a perplexing species from a taxonomic viewpoint on account of the variation in the papillae of the leaf cells. In some plants these papillae are well developed, but in others they are either so minute as to be scarcely visible or entirely wanting (Bartram 1933). We confirm this observation with our recent collections of this species from Kaua' $i$ Island. Indeed, it takes patience to search for the minute papillae on the leaf cells. The best location to see the series of minute leaf cell papillae is on the folded side of a leaf near the branch tip. Unfortunately, Câmara (2010) who claimed not being able to see the tiny leaf cell papillae proposed a transfer of this species to Sematophyllum which in our view is inaccurate. Our collections of this species from Kaua' $i$ also bear several sporophytes and the capsule wall shows only semi-collenchymatous exothecial cells. Furthermore, the alar cells of Taxithelium mundulum, though inflated in some leaves, are not of equal size and do not form a consistently well-organized basal row like the typical alar cells seen in the leaves of Sematophyllum species. We prefer to keep this species in Taxithelium pending a molecular confirmation of its generic affinity.

Trachypodopsis serrulata (P.Beauv.) M.Fleisch. var. crispatula (Hook.) Zanten [Meteoriaceae]

Specimens examined: Boundary of LĪHU`E AND KAWAIHAU DISTRICTS. Līhu'e Koloa Forest Reserve. Headwaters of the North Fork Wailua River on dripping wet rock faces, 600-670 m, 30 Oct 1992, Flynn, Lorence, Perlman \& Mehrhoff 5118 (COLO, Hoe Herb, PTBG), 11 Mar 1993, Flynn, Perlman \& Wood 5283 (COLO, Hoe Herb, NY, PTBG).

Trachypodopsis is a large and showy genus of about five species worldwide. The rustybrown coloration of this moss is diagnostic and plants generally grow in large lax mats. Trachypodopsis serrulata var. crispatula was previously reported only from the island of Hawai'i (Staples et al. 2004). Trachypodopsis auriculata (Mitt.) M.Fleisch. with a much broader distribution on several Hawaiian Islands differs from T. serrulata by its prominent leaf base auricles, leaves strongly plicate and leaf cells mostly smooth. 


\section{Vesicularia inflectens (Brid.) Müll.Hal. [Pylaisiaceae]}

Specimens examined: KAWAIHAU DISTRICT. Keālia Forest Reserve. Along Kuilau Trail at 0.5 mile marker above Keāhua Forestry Arboretum, 600 ft., 27 Sep 2014, Shevock, Ma \& Flynn 45997 (CAS, PTBG) and at end of the Kuilau Trail about 2 miles above and at beginning of Moalepe Trail, on volcanic boulders, $1140 \mathrm{ft}$., $27 \mathrm{Sep}$ 2014, Shevock, Ma \& Flynn 46012 (CAS, PTBG); LĪHU`E DISTRICT. Hoary Head Range, along road at intermittent streamlet below saddle between Queen Victoria's Profile and Hokulei Peak, 725 ft., 17 Feb 2016, Shevock, Flynn, Game \& Ma 48087 (CAS, KUN, PTBG); WAIMEA DisTRICT. Koke‘e State Park, off of highway 550 along Awa'awapuhi Stream, 4000 ft., 22 Jan 2015, Shevock, Flynn, Game \& Nyberg 46159 (CAS, PTBG).

The genus Vesicularia is a large genus with many poorly understood species. In the Hawaiian Islands, only two species of Vesicularia are documented. Vesicularia inflectens was reported only for the island of Maui by Staples et al. (2004) and can be separated from V. perviridis (Ångstr.) Müll.Hal. primarily by being more glossy and larger in appearance.

\section{Conclusion}

At some point when conducting moss floristic inventory work one has to decide when it is time to make new records available to the broader bryological community. We realize that there remain additional mosses to discover on Kaua ${ }^{6} i$ but we also feel compelled to publish the data we currently have available. Nonetheless, we have determined that much inventory and collection activities remain in this most isolated island chain.

Acknowledgements: We thank the various land management agencies on Kaua' $i$ for providing research collecting permits especially into forest reserves. Specimens identified by Carl Darigo $\dagger$, Catherine La Farge (Leucoloma), Benito C. Tan $\dagger$ (Sematophyllaceae), Mashuri Waite, and William Weber provided insights into species concepts and documentation for species distributions. David H. Lorence (PTBG) provided comments and corrections of an earlier version of this manuscript which we greatly appreciate. Without support from many colleagues this effort to update and revise the moss inventory of the Hawaiian Islands would not be possible.

\section{References}

Akiyama H. \& Shevock J.R. (2019): Two new species of Aptychella (Pylaisiadelphaceae, Musci) from Hawaiian Islands and Taiwan. - Bryological Research [in press].

Bartram E.B. (1933): Manual of Hawaiian mosses. - Bishop Museum Bulletin 101: 1-275.

- (1939): Supplement to the manual of Hawaiian mosses. - Bishop Museum Occasional Papers 15: 93-108.

Brotheru s V.F. (1927): Hawaiian mosses. - Bishop Museum Bulletin 40: 3-35 + viii plates.

Buck W.R. (1987): Notes on Asian Hypnaceae and associated taxa. - Memoirs of New York Botanical Garden 45: 519-527.

Câmara P.E.A.S. (2010): New combinations and one new name for the moss genus Taxithelium (Pylaisiadelphaceae). - Novon 20: 139-142.

Fleischer M. (1923): Die Musci der Flora von Buitenzorg Band 4. E.J. Brill, Leiden.

Frahm J.-P. (2011): A contribution to the moss flora of Hawaii, with the description of Breutelia griffinii sp. nov. - Tropical Bryology 33: 35-42.

Goffinet B., Buck W.R. \& Shaw A.J. (2009): Morphology, anatomy, and classification of the Bryophyta pp. 55-138. In: Goffinet \& Shaw (eds). Bryophyte Biology, second edition, Cambridge University Press.

Ho B.-C. \& Tan B.C. (2002): Additions to the moss flora of Endau Rompin National Park, Johore State, Peninsula Malaysia. - Tropical Bryology 22: 67-76.

Hoe W.J. (1974): Annotated checklist of Hawaiian mosses. - Lyonia 1: 1-45.

- (1978): Bryophyta Hawaiica exsiccata - the first century. - Bryologist 82: 79-82.

Huttunen S. \& Ignatov M.S. (2010): Evolution and taxonomy of aquatic species in the genus Rhynchostegium (Brachytheciaceae, Bryophyta). - Taxon 59 (3): 791-808.

Ireland R.R. (2014): Pseudotaxiphyllum, 559-562 pp. In: Flora of North America Editorial Committee (ed.), Flora of North America north of Mexico Volume 28 Bryoflora, part 2, Oxford University Press, New YorkOxford. 
Kim W. \& Yamaguchi T. (2017): Filibryum (Hypnaceae), a new moss genus with a new species from East Asia. - Journal of Bryology 39: 152-160.

La Farge C. (2002): Leucoloma III: A Species Synopsis: Typification, synonymy, and excluded names. Bryologist 105: 606-624.

Nishimura N. (1985): A revision of the genus Ctenidium (Musci). - Journal of the Hattori Botanical Laboratory 58: $1-82$

Noguchi A. (supplemented by Iwatsuki, Z. \& Yamaguchi, T.). (1994): Illustrated Moss Flora of Japan, Part 5. Hattori Botanical Laboratory, Nichinan.

Ramsay H.P., Schofield W.B. \& Tan B.C. (2002): The family Sematophyllaceae (Bryopsida) in Australia. Part 1. Introduction, family data, key to genera and the genera Wijkia, Acanthorrhynchium, Trismegistia and Sematophyllum. - Journal of Hattori Botanical Laboratory 92:1-50.

Schlesak S., Hedenäs L., Nebel M. \& Quandt D. (2018): Cleaning a taxonomic dustbin: placing European Hypnum in a phylogenetic context! - Bryophyte Diversity \& Evolution 40(2): 37-54.

Sharp A.J., Crum H., \& Eckel P.M. (eds.). (1994): The Moss Flora of Mexico. Part Two. The New York Botanical Garden, Bronx.

Staples G.W., Imada C.T., Hoe W.J. \& S mith C.W. (2004): A revised checklist of Hawaiian mosses. - Tropical Bryology 25: 35-69.

Tixier P. (1988): Le genre Glossadelphus Fleisch. (Sematophyllaceae, Musci) et sa valeur. - Nova Hedwigia 46: 319-356.

Waite M. (2007): Mosses of Hawai'i Volcanoes National Park. Technical Report 153, Pacific Cooperative Studies Unit, University of Hawai'i at Manoa, Honolulu. 55 pp.

Wynns J.T., Keith J.N., Murrell Z.E., McFarland K.D. \& Buck W.R. (2009): Studies on aquatic Oxyrrhynchium (Brachytheciaceae), with an emphasis on O. pringlei n. comb. Bryologist 112 (4): $786-803$.

Zander R.H. \& Hedderson T.A. (2016): Re-evaluation of Hymenostylium xanthocarpum (Hook.) Brid., and Ardeuma R.H. Zander \& Hedd., a new name for all other species of Hymenostylium (Pottiaceae, Bryophyta). - Journal of Bryology 39: 198-201.

Authors' addresses: James R. Shevock, California Academy of Sciences, Department of Botany, 55 Music Concourse Dr., Golden Gate Park, San Francisco, CA 94118, USA; National Tropical Botanical Garden, 3530 Papalina Road, Kalāheo, HI 96741, USA.

Tim Flynn, National Tropical Botanical Garden, 3530 Papalina Road, Kalāheo, HI 96741, USA.

John C. Game, National Tropical Botanical Garden, 3530 Papalina Road, Kalāheo, HI 96741, USA; University Herbarium, 1001 Valley Life Sciences, University of California, Berkeley, CA 94720, USA.

Wen Zhang Ma, California Academy of Sciences, Department of Botany, 55 Music Concourse Dr., Golden Gate Park, San Francisco, CA 94118, USA; Herbarium, Key Laboratory for Plant Diversity and Biogeography of East Asia, Kunming Institute of Botany, Chinese Academy of Sciences, 132 Lanhei Road, Kunming, Yunnan 650201, China.

Adam Williams, Department of Land and Natural Resources, Division of Forestry and Wildlife, 3060 Eiwa Street, Līhu'e, HI, 96766 USA.

David R. Toren, California Academy of Sciences, Department of Botany, 55 Music Concourse Dr., Golden Gate Park, San Francisco, CA 94118, USA.

John R. Spence, California Academy of Sciences, Department of Botany, 55 Music Concourse Dr., Golden Gate Park, San Francisco, CA 94118, USA; National Park Service, Glen Canyon National Recreation Area, P.O. Box 1507, Page, AZ 86040, USA. 